Research article

\title{
Comparative studies on some biochemical parameters of Cajanus scarabaeoides (L.) Thouars and Cajanus cajan (L.) Millsp.
}

\author{
Joyeeta Dey*, Puja Rani Saha, Priyanki Debnath and R. K. Sinha \\ Plant Physiology and Biochemistry Lab., Department of Botany, Tripura University, Tripura, India \\ *Corresponding Author: joyeeta.dey10@gmail.com \\ [Accepted: 18 August 2017]
}

\begin{abstract}
Studies of some biochemical parameters in wild Cajanus scarabaeoides was carried out and compared with Cajanus cajan as its cultivated relative. C. scarabaeoides is considered to have a potent source of genetic variation carrying genes for resistance to various biotic and abiotic stresses and other morphological traits. Comparative analysis of biochemical parameters revealed distinct genomic diversity between the two species. Electrophoretic study of leaf isoperoxidases in two species of Cajanus indicated the presence of species specific variability in terms of relative mobility values of isozymes. Higher values of total amino acids, sugar and protein content in $C$. scarabaeoides also indicates ethnobotanical significance of the species as compared to widely cultivated C. cajan.
\end{abstract}

Keywords: Cajanus species - Biochemical attributes - Isoperoxidase - Genomic diversity.

[Cite as: Dey J, Saha PR, Debnath P \& Sinha RK (2017) Comparative studies on some biochemical parameters of Cajanus scarabaeoides (L.) Thouars and Cajanus cajan (L.) Millsp. Tropical Plant Research 4(2): 314-318]

\section{INTRODUCTION}

Cajanus scarabaeoides (L.) Thouars belongs to the family Fabaceae, locally known as Bonkalai. This species is the closest wild relative to Cajanus cajan (L.) Millsp. [Pigeon pea]. C. scarabaeoides is reported to be used as ethnomedicine by the tribal healers around different states of India. Tribal people of Madhya Pradesh use the plant decoction as a tonic after delivery; the fresh leaf paste is applied on swellings of leg. The pods are also eaten for this purpose. In Bihar tribal people use the root paste and use it with coconut oil to check falling hairs to cure baldness (Sharma \& Kumar 2013). Native people of Andhra Pradesh use this plant to cure piles (Murty \& Rao 2010), skin diseases (Rao et al. 2006). This plant is also used as fodder and effective in reducing diarrhea in cattle. Besides, the species is an important weed legume with various ethnomedicinal properties. It also possesses wound healing, anti-diabetic, anti-inflammatory, hepatoprotective, anti-diarrheal, anti-bacterial activities (Pattanayak et al. 2009, 2011). Significance of $C$. scarabaeoides as a source of ethnobotanicals in terms of carotenoid content was recorded (Dey \& Sinha 2015). C. scarabaeoides was also reported to have higher levels of draught tolerance, and resistance to insect pests compared to cultivated types (Tikka et al. 1997). The genetic traits of drought tolerance and the higher levels of resistance to insect pests of Cajanus scarabaeoides can be utilized to improve the crop's productivity of Cajanus cajan (Sharma et al. 1987, Upadhyaya et al. 2011). In view of the above context, the present study is aimed to study certain biochemical attributes of wild $C$. scarabaeoides and its comparision with cultivated $C$. cajan.

\section{MATERIALS AND METHODS}

The two species, Cajanus cajan (L.) Millsp. and Cajanus scarabaeoides (L.) Thouars were collected in an around Suryamaninagar area (Fig. 1) of West Tripura district; having a geographical location of N 23⒋ $45^{\prime} 40.6^{\prime \prime}$ and E $091^{\circ} 16^{\prime} 04.3^{\prime \prime}$. The healthy plant materials were collected during the month of March, 2016. Herbarium specimen of respected species were prepared and identified with the help of floristic literature (Deb 1983, Hooker 1885). The herbarium specimen with accession number TU/BOT/471 and 472 were assigned for $C$. cajan and C. scarabaeoides respectively and submitted to the herbarium of the Department of Botany, Tripura University for reference (Fig. 2).

Healthy fresh leaves were used as a source of ethnobotanicals purposes and thus biochemical investigation 
of respective species were performed to estimate the total soluble sugar with Anthrone Reagent by the method of Yemm \& Willis (1954). In this, $500 \mathrm{mg}$ freshly harvested leaves of plants were homogenized in $10 \mathrm{ml}$ of $50 \%$ aqueous ethanol with a pinch of activated charcoal. The slurry was centrifuged at $5000 \mathrm{rpm}$ for $10 \mathrm{~min}$ and free amino acids were extracted in the form of a clear supernatant. The volume of supernatant was raised to 10 $\mathrm{ml}$ with aqueous $50 \%$ ethanol. To $1 \mathrm{ml}$ of the supernatant $2 \mathrm{ml}$ of $2 \%$ freshly prepared anthrone reagent was added. The absorbance of the green coloured complex was taken at $620 \mathrm{~nm}$. Glucose was used as standard.

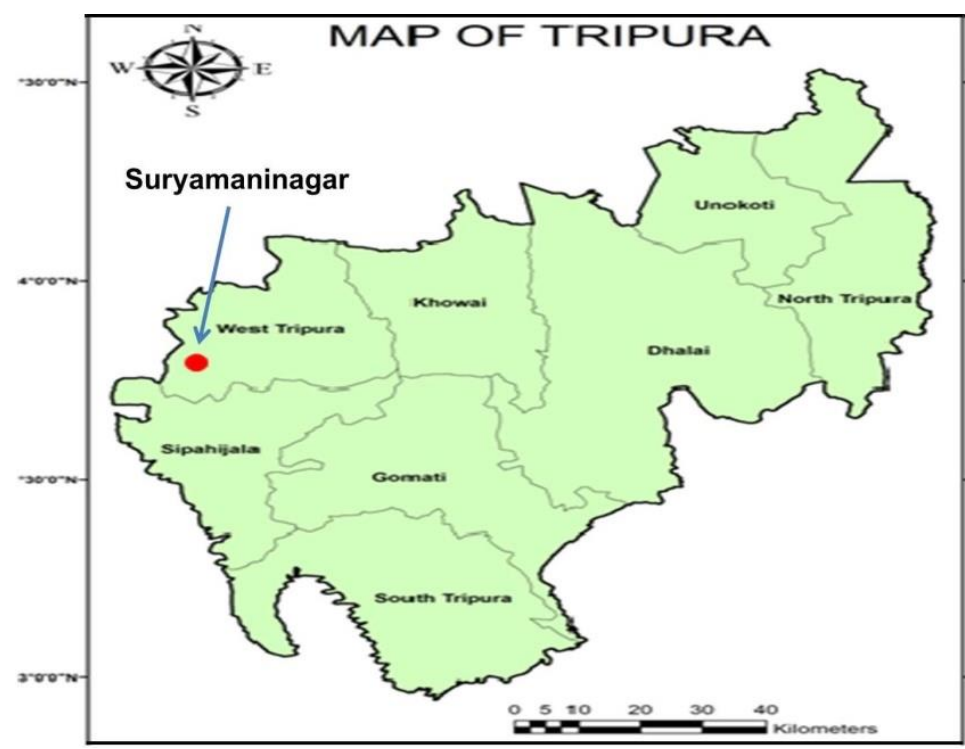

Figure 1. Map showing the study area (Suryamaninagar) of the West Tripura district, Tripura.
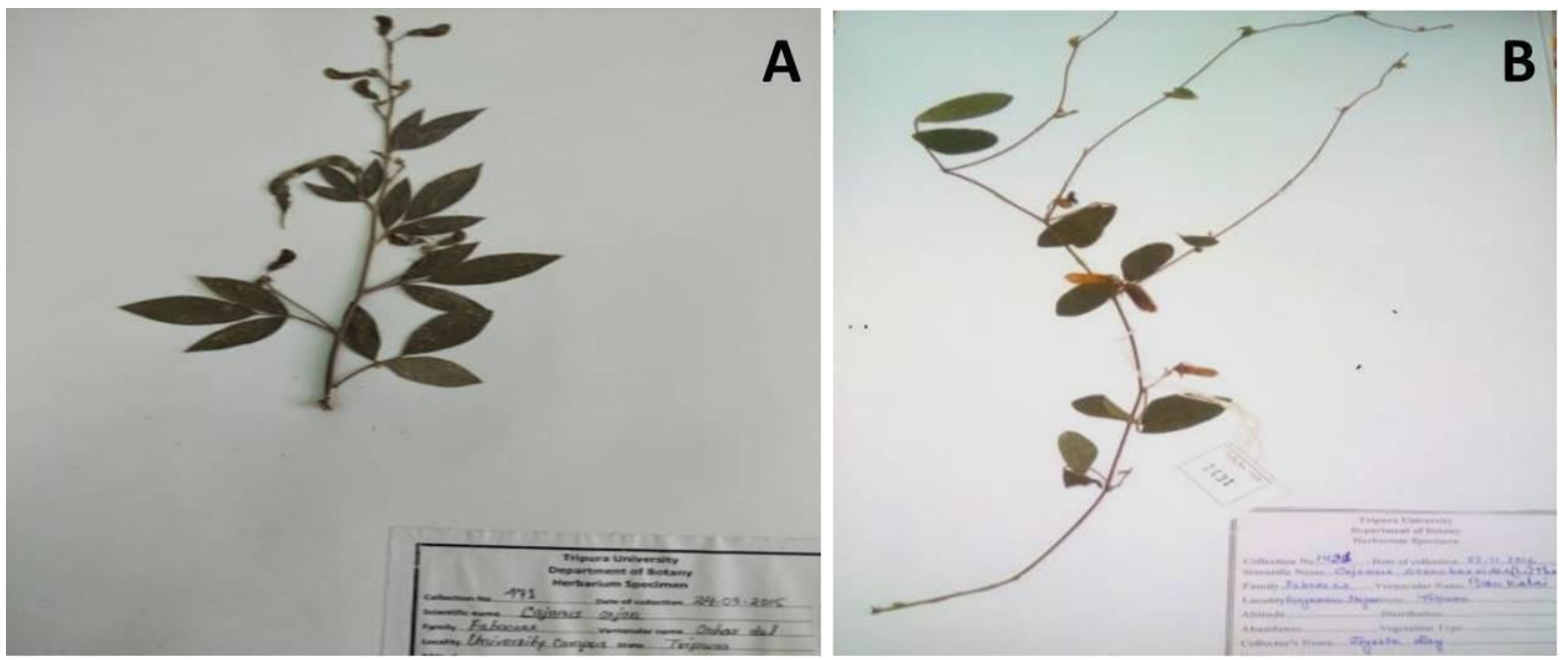

Figure 2. A, Herbarium specimen of Cajanus cajan; B, Herbarium specimen of Cajanus scarabaeoides.

The amount of total free amino acid was estimated following the method of Yemm \& Cocking (1955). Freshly harvested leaves $(500 \mathrm{mg}$ ) of plants were homogenized in $10 \mathrm{ml}$ of $50 \%$ aqueous ethanol with a pinch of activated charcoal. The slurry was centrifuged at $5000 \mathrm{rpm}$ for $10 \mathrm{~min}$ and free amino acids were extracted in the form of a clear supernatant. The volume of supernatant was raised to $10 \mathrm{ml}$ with aqueous $50 \%$ ethanol. To 1 $\mathrm{ml}$ of the supernatant $2 \mathrm{ml}$ of $2 \%$ Ninhydrin (w/v in dehydrated alcohol) was added. The mixture was kept on water bath at $75 \pm 2{ }^{\circ} \mathrm{C}$ for 10 minutes and after cooling, aqueous alcohol $(1: 1)$ was added to make up the volume to $3 \mathrm{ml}$. The absorbance of the violet complex was measured at $570 \mathrm{~nm}$ on a spectrophotometer. The amount of total free amino-acids was calculated with the help of a standard curve prepared from glycine and was expressed as mg of amino acids per gram fresh weight of the sample.

The phosphate buffer soluble protein was estimated following the procedure of Lowry et al. (1951). Fresh leaves $(500 \mathrm{mg})$ were crushed in $5 \mathrm{ml}$ cold potassium phosphate buffer solution $(\mathrm{pH} 7.5 ; 0.1 \mathrm{M})$ on ice-bath using pestle and mortar. The homogenate was filtered through cheese cloth and the filtrate was centrifuged at $12000 \mathrm{rpm}$ for $25 \mathrm{~min}$ in a refrigerated centrifuge. The supernatant was taken in a $10 \mathrm{ml}$ measuring cylinder and 
its volume was raised to $10 \mathrm{ml}$ with same buffer. The pellet was used for insoluble protein. This supernatant contains soluble protein. In $1 \mathrm{ml}$ of supernatant $1 \mathrm{ml}$ of tri-chloro acetic acid (TCA) solution (10\%, w/v) was added in a centrifuge tube. Immediately a whitish or cream coloured precipitate appeared. The precipitate was centrifuged at $5000 \mathrm{rpm}$ for $5 \mathrm{~min}$ and after centrifugation the supernatant was discarded and the pellet contained precipitate of soluble protein. To this pellet $2 \mathrm{ml}$ of ethyl alcohol (95\%) was added and stirred the precipitate so as to remove the TCA sticking on the surface of the protein as well as to remove pigments, if any. The tube containing the precipitate was re-centrifuged (1000 rpm for $5 \mathrm{~min}$ ) and the supernatant was discarded. The pellet was used for estimation of soluble protein using reagents prescribed in the Lowry method and the absorbance of blue colour complex was read at $690 \mathrm{~nm}$ using Spectrophotomter. BSA was used as standard protein.

The amount of total soluble phenol were determined by the following the methods Swain \& Hillis (1959). For this $500 \mathrm{mg}$ fresh leaves were taken and crushed with $80 \%$ chilled ethanol. Then the slurry was centrifuged at $5000 \mathrm{rpm}$ for 20 mins. The supernatant was collected and evaporated to dryness. After drying the pellet was dissolved in water and this was used as aliquot. From this aliquot $0.05 \mathrm{ml}$ was taken in a test tube and $0.5 \mathrm{ml}$ Folin reagent, $2.5 \mathrm{ml}$ distilled water and $2 \mathrm{ml}$ saturated sodium carbonate solution were gradually added. The OD of the blue coloured complex was taken at $560 \mathrm{~nm}$. Tannic acid was used as a standard.

Assay of in vivo Nitrate Reductase was measured in fresh leaves by the method of Hageman \& Hucklesby (1971). Fresh $500 \mathrm{mg}$ leaves were cut into thin strips $(2 \mathrm{~mm} \times 3 \mathrm{~mm}$ size $)$ from respective plant species and incubated in the assay mixture containing $4 \mathrm{ml}$ of potassium-phosphate buffer $(0.1 \mathrm{M} ; \mathrm{pH} 7.4), 0.5 \mathrm{ml} \mathrm{KNO}_{3}$ $(100 \mathrm{mM})$ and $0.5 \mathrm{ml}$ of $5 \%$ aqueous propanol. After 30 mins of incubation period at $32 \pm 2{ }^{\circ} \mathrm{C} 1 \mathrm{ml}$ of incubated assay was transferred to a test tube contain $1 \mathrm{ml}$ of sulphanilamide and $1 \mathrm{ml}$ of NED mixture. The pink coloured complex was used for determination of nitrite spectrophotometrically at $540 \mathrm{~nm}$. Sodium nitrate was used as standard. Antioxidant activity in the leaves was measured by following the method of Patel \& Patel (2011).

For isozyme study slab vertical polyacrylamide (without SDS) gel electrophoresis (Laemmli 1970) was adopted. In this process, $500 \mathrm{mg}$ freshly harvested leaves were taken and homogenized in $3 \mathrm{ml}$ extraction buffer in cold; and the homogenate was centrifuged at $12,000 \mathrm{rpm}$ for 45 mins at $4^{\circ} \mathrm{C}$ for $7-8$ times. The supernatant was collected and used as the material source for isozyme study. For the isozyme study, the vertical PAGE was performed without using SDS. Respective mean values of the biochemical attributes were compared following the simple students's ' $\mathrm{t}$ ' test between the means.

\section{RESULTS AND DISCUSSION}

Total free amino acid and soluble sugar was found to be higher in the leaves of $C$. scarabeoides (Table 1) whereas the amount of total soluble phenol was significantly higher in $C$. cajan. Efficiency of nitrate reductase activity was much higher and significant in $C$. cajan though soluble protein content was almost similar in both the species. The antioxidant activity measured in the leaves of $C$. scarabaeoides was $45.54 \%$ inhibition and much less against the reported data of $C$. cajan (Mahitha et al. 2015).

Table 1. Comparison of some biochemical parameters of Cajanus cajan and Cajanus scarabaeoides.

\begin{tabular}{llll}
\hline Parameter & Cajanus cajan & Cajanus scarabaeoides & t-value \\
\hline $\begin{array}{l}\text { Total free amino acid } \\
\text { (mg.g } \text { fresh wt.) }^{-1}\end{array}$ & $5.59 \pm 0.50$ & $7.18 \pm 0.95$ & $3.31^{*}$ \\
$\begin{array}{l}\text { Soluble sugar } \\
\text { (mg.g }{ }^{-1} \text { fresh wt.) }\end{array}$ & $6.67 \pm 1.20$ & $8.34 \pm 1.44$ & $1.99(\mathrm{NS})$ \\
$\begin{array}{l}\text { Soluble phenol } \\
\left(\mathrm{mg}^{-1} \text { fresh wt.) }\right.\end{array}$ & $1.29 \pm 0.12$ & $0.97 \pm 0.08$ & $4.96^{*}$ \\
$\begin{array}{l}\text { Soluble protein } \\
\left(\mathrm{mg} . \mathrm{g}^{-1} \text { fresh wt.) }\right.\end{array}$ & $28.21 \pm 1.74$ & $28.26 \pm 1.22$ & $0.06(\mathrm{NS})$ \\
$\begin{array}{l}\text { Antioxidant activity } \\
\text { Nitrate reductase activity } \\
\left(\mu \text { moles } \mathrm{NO}_{2} \text { produced } \mathrm{h}^{-1} \mathrm{~g}^{-1} \text { leaf fr. wt.) }\right.\end{array}$ & $\dagger 52.12 \%$ (inhibition) & $45.54 \%$ (inhibition) & - \\
\hline
\end{tabular}

Note: *Significant at 5\% level; NS= Not Significant; **Mean of five replicates (†source: Mahitha et al. 2015).

Cajanus scarabaeoides is having high ethnomedicinal values as it is used in tonic after delivery, fresh leaf paste or pod used to cure swelling of leg, root paste also used in night fever, dropsy, anaemia, burns and wounds by the indigenous people of Tripura (Majumdar \& Datta 2013). Since leaves are also used as vegetables by 
certain communities (Choudhury et al. 2015), the present study highlights significant differences in terms of high soluble sugar and free amino acid content as compared to C. cajan. The antioxidant property and phenolic contents of the leaves are however superior in $C$. cajan. Soluble protein content in the leaves is very close between the two taxa in spite of high Nitrate Reductase activity recorded in $C$. cajan. Iso-enzyme pattern reveal remarked genetic differences between the two taxa. As many as seven isozymes were recorded in $C$. cajan with different relative mobility $(\mathrm{Rm})$ values ranging from $0.08-0.61$ compared to five isozymes ranging from $0.08-$ 0.59 in C. scarabaeoides (Fig. 3). Only three isozymes were found common in both the species. In spite of differences in many biochemical traits and isozyme patterns between the two taxa, $C$. scarabaeoides is reported to be compatible with $C$. cajan. Successful $F_{1}$ hybrid production between the two taxa was already reported by other workers (Mishra et al. 2012). This result also suggests that genetic distance between cultivated $C$. cajan and its wild relative is not related to their hybridization barrier as also reported by Mudaraddi et al. (2013).
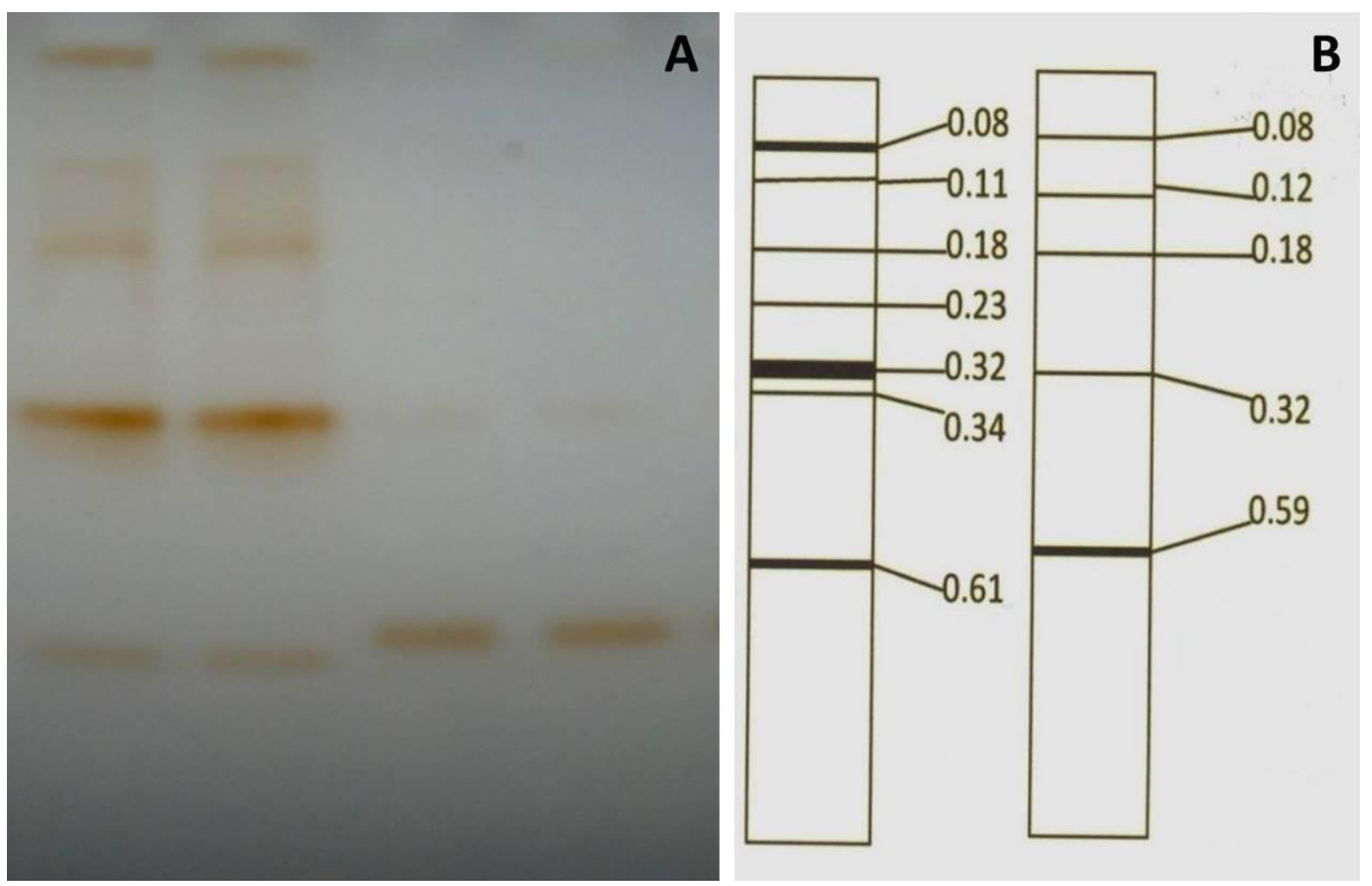

Figure 3. Zymogram pattern of leaf isoperoxidases: A, Cajanus cajan; B, Cajanus scarabaeoides.

\section{CONCLUSION}

The present study highlights the genetic diversity of wild $C$. scarabaeoides in terms of certain biochemical attributes and its relative significant difference in free amino acids, phenol contents and nitrate reductase activities between the two species. Relatively high value of soluble sugar and protein contents is also attributing characteristic of nutritional value of $C$. scarabaeoides leaves.

\section{ACKNOWLEDGEMENT}

Authors are thankful to the University Grants Commission, (UGC) New Delhi for providing financial support to the Department of Botany, Tripura University, Suryamaninagar - 799022, India.

\section{REFERENCES}

Choudhury J, Bora D, Baruah D, Borah T \& Bharali BK (2015) Traditional folk medicinal practices among the indigenous people of Dhalai district of Tripura. Journal of Drug Research in Ayurvedic Sciences 1(10): 3246.

Deb DB (1983) Flora of Tripura. Today and Tomorrow's Printers and Publishers, pp. 124-192.

Dey J \& Sinha RK (2015) Carbon and nitrogen metabolites in some ethno-botanical weed legumes of Tripura during their seasonal maturity of growth. Annals of Biological Research 6(2): 1-3.

Hageman RH \& Hucklesby DP (1971) Nitrate reductase from higher plants. In: San Pietro A (ed) Methods in www.tropicalplantresearch.com 
Enzymology. Academic Press, London, pp. 491-503.

Hooker JD (1885) Flora of British India. Published under the authority of the secretary of state for India in council. Vol 4. L. Reeve, London.

Laemmli UK (1970) Cleavage of structural proteins during the assembly of the head of bacteriophage T4. Nature 227(5259): 680-685.

Lowry OH, Rosenbrough NJ, Farr AL \& Randoll RJ (1951) Estimation of protein with the folin-phenol reagent. Journal of Biological Chemistry 193: 265-275.

Mahitha B, Archana P, Ebrahimzadeh MH, Srikanth K, Rajinikanth M \& Ramaswamy N (2015) In vitro Antioxidant and Pharmacognostic Studies of Leaf Extracts of Cajanus cajan (L.) Millsp. Indian Journal of Pharmaceutical Sciences 77(2): 170-177.

Majumdar K \& Datta BK (2013) Practice Pattern of Traditional Pharmaceutical Formulations by the Tribes of Tripura, Northeast India. Global Journal of Pharmacology 7 (4): 442-447.

Mishra RR, Sahu AR, Rath SC \& Panigrahi J (2012) Cyto-morphological and molecular characterization of Cajanus cajan $\mathrm{x}$ Cajanus scarabaeoides $\mathrm{F}_{1}$ hybrid. Nucleus 55(1): 27-35.

Mudaraddi B, Saxena KB, Saxena RK \& Varshney RK (2013) Molecular diversity among wild relatives of Cajanus cajan (L) Millsp. African Journal of Biotechnology 12(24): 3797-3801.

Murty PP \& Rao GMN (2010) Unique ethnomedicinal uses of some plant species of Andhra Pradesh, India. Journal of Phytology 2(4): 17-21.

Patel RM \& Patel NJ (2011) In vitro antioxidant activity of coumarin compounds by DPPH, super oxide and nitric oxide free radical scavenging methods. Journal of Advanced Pharmacy Education \& Research 1: 52-68.

Pattanayak S, Nayak SS \& Panda D (2009) Hypoglycemic of Cajanus scarabaeoides in glucose overloaded and streptozotocin-induced diabetic rats. Journal of the Bangladesh Pharmacological Society 4: 131-135.

Pattanayak S, Nayak SS, Dinda SC, Panda DP \& Navale KP (2011).Evaluation of herbal ointments formulated with methanolic extract of Cajanus scarabaeoides. Journal of Pharmacy and Allied Health Sciences 1(2): 49-57.

Rao DM, Rao UVUB \& Sudharshanam G (2006) Ethno-Medico-Botanical Studies From Rayalaseema Region Of Southern Eastern Ghats, Andhra Pradesh, India. Ethnobotanical Leaflets 10: 198-207.

Sharma D, Kannaiyan J \& Saxena KB (1987) Sources of resistance to Alternia blight in pigeonpea. Sabrao Journal 19(2): 109-114.

Sharma M \& Kumar A (2013) Leguminosae (Fabaceae) in Tribal Medicines. Journal of Pharmacognosy and Phytochemistry 2(1): 276-283.

Swain T \& Hillis WE (1959) The phenolic constituents of Purmus domestica. I. The quantitative analysis of phenolic constituents. Journal of Science Food and Agriculture 10: 63-68.

Tikka SBS, Parmar LD \& Chauhan RM (1997) First record of cytoplasmic-genic male sterility system in pigeonpea (Cajanus cajan(L.) Millsp.) through wide hybridization. Gujarat Agriculture University Research Journal 22: 160-162.

Upadhyaya HD, Dronavalli N, Gowda CLL \& Singh S (2011) Identification and evaluation of chickpea germplasm for tolerance to heat stress. Crop Science 51: 2079-2094.

Yemm EW \& Cocking EC (1955) The determination of amino-acids with ninhydrin. Analyst 80: 209-213.

Yemm EW \& Willis AJ (1954) The estimation of carbohydrates in plant extracts by anthrone. Biochemical Journal 57: 508-514. 